\title{
A Study About The Role of Cronyism Perceptions of Tourism Employees upon Their Career Plateu
}

\author{
Nihan YAVUZ AKSAKAL (iD a Ebru ULUCAN ${ }^{\text {(D) }}$ b \\ a İstanbul Ticaret University, İstanbul, Turkey. nyavuz@ticaret.edu.tr \\ b İstanbul Ticaret University, İstanbul, Turkey. eulucan@ticaret.edu.tr
}

\begin{tabular}{|c|c|}
\hline ARTICLE INFO & ABSTRACT \\
\hline Keywords: & Purpose - This study was conducted tries to reveal if cronyism is a problem in tourism sector just like \\
\hline Cronyism & in others, or not. For this reason, the main purpose of this study is to measure the tourism employees' \\
\hline Career plateau & cronyism perceptions and their career plateau experience arising from cronyism. \\
\hline Tourism enterprises & $\begin{array}{l}\text { Design/methodology/approach - This study was conducted with qualitative research methods and } \\
\text { designed with exploratory research pattern. Interviews were made with } 23 \text { employees who work in } \\
\text { different tourism enterprises. During the interviews, eight questions were asked to the participants and }\end{array}$ \\
\hline
\end{tabular}

Received 6 July 2021

Revised 8 November 2021

Accepted 20 November 2021

Article Classification:

Research Article
Findings - As a result, it was revealed that tourism employees were aware of cronyism in their companies, and cronyism mostly showed itself in promotion, salary increase and workload distribution. Because of the cronyism seen in promotions, employees emphasized that they began to feel distrust and did not see a future for themselves in their companies. This result shows that the cronyism experienced in tourism enterprises also causes the employees to experience a career plateau. In addition to all these results, this research is also important in that it is the first study in the literature to establish a direct relationship between cronyism and career plateau in the tourism sector.

Discussion - Regardless of the sector, employees think that when they are faced with cronyism, they cannot be promoted and plan their careers as they are just because of cronyism. All of this result with cynical behaviors and being alienated to the companies and the sector itself.

\section{Introduction}

Among the expectations of employees in organizations accepted as social and living assets; objective and fair behavior is one of the most important elements. Ensuring the harmony between the structures, functioning and individuals in organizations, where individuals with different characteristics coexist, is possible by acting fairly and by preventing in favouritism behaviors. Cronyism, which emerges through social networks, is probably the most common form of favouritism behavior in organizations due to its wide boundaries. Cronyism, which is the situation of individuals to be recruited, remuneration, career development, and benefit from various working conditions because of the long-term personal relationships, not because of their education level, success, abilities and performances, (Drew et al., 2012); is also considered an important concept in dynamic and labor-based tourism enterprises. Because the phenomenon of favouritism, which is frequently encountered in public and commercial life, is also seen in tourism enterprises operating in the service sector and where the "human" factor is indispensable (Şapçlar, 2017). This situation shows itself mostly in selecting the opening team employees in the newly opened enterprises among the managers' affinities. Although this situation seems like it accelerates the activities and success of the enterprises in the opening process, when considered in the long term; it reduces the possibility of unacquaint new personnel to be accepted and promoted within the company. Especially when employees realize that some of their teammates are better known and liked by managers, they are negatively affected by this and fall into a mistrust towards their company and experience anxiety for the future.

As in many other sectors, as a result of tourism employees' lack of career planning for their future due to their insecurity; career plateau phenomenon arises in tourism sector as well. Issues such as recruitment, 


\section{N. Yavuz Aksakal - E. Ulucan 13/4 (2021) 3164-3180}

performance, career, promotion; which employees use to evaluate a company's justice, equality and trust in the organizational environment; are also related to the individual goals of the employees. These individual goals include promotion, career development, etc. and the hindrance of these goals creates career plateu which can occur because of many reasons. One of these reasons is that employees, who have better personal connections with top management due to favouritism, are promoted more often and remain in these positions for a long time. At this point, it is also possible to say that there is a relationship between cronyism and the career plateau (Bolat et al., 2017).

In this study, cronyism, which is one of the behaviors that limit the paths of success (Khatri et al., 2003), and career plateau are evaluated in terms of tourism enterprises. In the first part of the study, the concepts of cronyism and career plateau are explained and previous studies on the subject in the literature are included. In the second part, the application process and findings of the research are given. The study was concluded with the recommendations developed for both industry representatives and other researchers on the subject.

\section{Literature Review}

\subsection{Cronyism}

In general, favouritism behavior can be defined as rewarding or recruiting people for being a member of a certain group, having social relationships or other desirable characteristics instead of having good skills and knowledge (Nadler \& Schulman, 2006). In general, favouritism behavior can be seen in different types such as nepotism, cronyism, favorism, tribalism and guanxi. Nepotism can be defined as unethical privilege of individuals with blood or kinship relations (Abdalla et al., 1998).

While favorism, which includes subjectivity or prejudice based on individual preferences, falls within the definition of cronyism, it is narrower when considering social connections and processes. (Khatri et al., 2008). The favouritism of people belonging to the same tribe is expressed as tribalism. (Loewe et al., 2007). Guanxi, includes long-term connections and relationships with resources based on trust and reputation (Khatri et al., 2006). Cronyism, on the other hand, was created by a group of people working together to develop and maintain an informal system for personal gain rather than formal rules and procedures (James, 2006).

Cronyism, which is derived from the words "khronios" in Greek and "crony" in English, means "long-term friendship and good fellowship" and, is also often used in the literature as friendly favouritism (Kiechel, 1984; Büte, 2011). The concept of cronyism was suggested firstly in the 1840s as "the ability or desire to make friends" (Khatri \& Tsang, 2003) and has been variously described by different authors over time. Cronyism is the fact that individuals hold a certain position through their social network connections and interpersonal relationships, rather than their knowledge, skills and abilities (Khatri et al., 2003).

Cronyism is a personnel practice applied in processes such as non-merit-based recruitment or promotion, especially as a result of friendship with an individual in a managerial position (Hernandez \& Page, 2006). According to a different definition, it is seen as being on the side of friends or acquaintances of friends (Pelletier \& Bligh, 2008). According to Chandler (2012), cronyism is an application based on privileged behavior and not based on merit.

Although the concepts of nepotism and cronyism are quite similar, their difference is that the behavior of favouritism in general varies according to the degree of closeness. Boadi (2000: 198) suggests that cronyism is a larger phenomenon than nepotism and favouritism is directed towards friends and colleagues. In addition, nepotism is thought to be narrower since it includes only family and kinship ties (Khatri et al., 2008:6; Yan \& Bei, 2009: 3). Another similar concept, guanxine, has three properties that differ from cronyism. These characteristics are that the relationship is not passed down from generation to generation, the network of relationships does not harm third parties, and although guanxine is not favouritism itself, it leads to favouritism in general. (Khatri et al., 2006). Considering all the definitions made; it would not be wrong to say that the common point of all types of favouritism is not complying with the merit system and ignoring individuals' knowledge, skills, education and abilities.

Cronyism is a social phenomenon and a form of favouritism based on social network connections and interpersonal relationships. Since it is a social phenomenon, cronyism can be seen for various reasons, and since relationships are dynamic, cronyism is also dynamic and proactive (Khatri et al., 2003). Since cronyism 


\section{N. Yavuz Aksakal - E. Ulucan 13/4 (2021) 3164-3180}

has a dynamic structure, social groups with which individuals are close or interests may change over time. This situation moves the concept of cronyism away from the idea of "long-term friendship and good fellowship", which was the first derived meaning of the word, and reflects the view that a "long-term" relationship may not be necessary in order to see cronyism (Khatri et al., 2003). Cronyism is also known as a method that targets unethical and prejudiced employment practices and certain groups with different cultural backgrounds (Jones et al., 2008).

According to Khatri et al. (2006), four elements must be found in order to see cronyism. Firstly, either party does not have to immediately see a favor from the other, or that the favor has not to be contractual. Secondly, one side should see a tangible (like promotion) or intangible (like information) favor from the other. Thirdly, there should be a social bond between the two parties (such as kinship, friendship, ethnicity, business friendship). Lastly, the relationship between the two parties (the creation of cronyism) must cause a cost/loss to the third party who rejects a more valuable resource.

Cronyism, which is a kind of favouritism shown to the subordinates by the individual in the managerial position, can be seen at the organizational and individual level. It is stated that cronyism can be observed at the organizational level due to the political connections of the organization, and at the individual level through the friend in the organization (Soleimanof, 2016). This kind of favouritism can be observed for the purposes of reciprocity and gain (Khatri et al., 2003).

Cronyism can be observed in different ways with the unfair use of power and authority in organizations. In organizations, it can occur as intra-group bias cronyism and paternalistic cronyism. In-group bias cronyism, in a certain social environment, the individual tends to apply a kind of cronyism by including individuals whom he feels close to into the group, while placing individuals he does not feel close to in the outer group. Psychological interdependence among groups as a result of intra-group bias cronyism, informality and informal relationships emerge in the organization. The concepts of power and loyalty are at the forefront in paternalistic cronyism. It is a situation where managers direct their resources to their subordinates whom they trust and find loyal, and in return they expect obedience and loyalty from their subordinates (Turhan, 2014).

Disregarding the knowledge, skills and abilities of the employees and managing the processes with favouritism, on the other hand, brings up many issues in organizations on an individual and organizational basis. These issues mostly show themselves as the effects of cronyism. While some of the studies argue that cronyism may be advantageous, the majority of the studies highlight the negativities that cronyism can create in employees and organizations. Accordingly, the advantages and disadvantages of cronyism are summarized in Table 1 (Hurley et al., 1997; Khatri \& Tsang, 2003; Khatri et al., 2008; Xin-Zhi et al., 2010; Pearce, 2015).

Table 1. Advantages and Disadvantages of Cronyism

\begin{tabular}{|c|c|}
\hline Advantages & Disadvantages \\
\hline $\begin{array}{l}\square \text { Organizational decision making process can } \\
\text { be shortened. } \\
\square \text { The organization can use its network to find } \\
\text { new markets and new resources. } \\
\square \text { Communication may become faster as a } \\
\text { result of close relationships. } \\
\square \text { Group members involved in cronyism may } \\
\text { have more job satisfaction than those } \\
\text { outside. }\end{array}$ & $\begin{array}{l}\text { \ince interpersonal relationships are at the } \\
\text { forefront, fair evaluation becomes difficult. } \\
\text { The desire of the employees to receive } \\
\text { training is decreasing. } \\
\text { Employees slow down their work flow by } \\
\text { losing motivation and confidence in the } \\
\text { business. } \\
\text { Negative effects are seen on the job } \\
\text { satisfaction of the employees. } \\
\text { While some of the employees have better } \\
\text { career conditions, the rest of the employees } \\
\text { are faced with career plateau. }\end{array}$ \\
\hline
\end{tabular}

Source: Compiled by the authors.

\subsection{Career Plateau}

Currently, the difficulty of competitive conditions, fast-developing technology, social changes and developments affect organizations that are living beings, just like people. In rapidly changing competitive 
conditions, organizations can make a difference with the human resources they have. For this reason, placing the right individuals in the right positions is a good tool for achieving this goal.

Placing the right people in the right position is associated with both recruitment processes and career and promotion processes. At this point, within an organization, it is important to be able to plan careers, manage careers and talents in such a way that the harmony between the needs of the organization and employees is balanced (Baoguo \& Mian, 2005). With properly designed career management, the abilities that exist in the organization can be retained, the monotony of employees at work can be prevented; the employee can improve with individual career planning and as a result, the person can be assigned in different positions horizontally or vertically.

The career plateau, the first definition of which was proposed by Ference, Stoner and Warren (1977) as a low possibility of rising in a career, has also been considered from different angles over time. The concept was expanded as the employee mastered all his/her duties, had nothing new to learn, and perceived stagnation in his/her career (Cheng \& Su, 2017). According to Tan and Salomone (1994), the lack of career progression in the organization in vertical or horizontal direction is defined as career plateau. Career plateau, which is a psychological feeling according to another point of view, is also accepted as the frustration and inability that employees feel due to a temporary or permanent stop in career progression (Rotondo \& Perrewe, 2000). According to Nachbagauer and Riedl (2002), it is the absence of progress in a hierarchical or task-oriented manner. In time, the career plateau has been handled with different dimensions and many plateau types have been defined. The classification of career plateau done by various researches are shown as follows in Table 2 .

Table 2. The Classification of Career Pletau

\begin{tabular}{|c|c|c|c|c|}
\hline Ference et al. (1977) & Bardwick (1986) & $\begin{array}{l}\text { Xie, Lu, Zhou and } \\
\text { Xin (2014) }\end{array}$ & Lee (2003) & $\begin{array}{ll}\text { Godard, } & \text { Fouque, } \\
\text { Gollety and Flanchec } \\
(2015)\end{array}$ \\
\hline $\begin{array}{l}\text { The individual plateau } \\
\text { - caused by the } \\
\text { employees' lack of } \\
\text { qualifications or lack } \\
\text { of desire to be } \\
\text { promoted although } \\
\text { there are } \\
\text { opportunities for } \\
\text { promotion. }\end{array}$ & $\begin{array}{l}\text { The hierarchical } \\
\text { plateau - is lack of } \\
\text { promotion } \\
\text { opportunities }\end{array}$ & $\begin{array}{l}\text { The hierarchical } \\
\text { plateau - same as } \\
\text { Bardwick }\end{array}$ & $\begin{array}{l}\text { The professional } \\
\text { plateau - means } \\
\text { a stagnation in } \\
\text { professional } \\
\text { development } \\
\text { and acquisition } \\
\text { of new skills in } \\
\text { terms of both } \\
\text { job content and } \\
\text { employability }\end{array}$ & $\begin{array}{l}\text { The objective plateau - } \\
\text { structural and } \\
\text { observable elements } \\
\text { and is usually } \\
\text { measured on the basis } \\
\text { of seniority or salary }\end{array}$ \\
\hline \multirow[t]{2}{*}{$\begin{array}{l}\text { The organizational } \\
\text { plateau - having no } \\
\text { opportunities in the } \\
\text { organization despite } \\
\text { the appropriate } \\
\text { qualifications of the } \\
\text { employee. }\end{array}$} & $\begin{array}{l}\text { The job content } \\
\text { plateau - is lack of } \\
\text { responsibility due } \\
\text { to the nature of } \\
\text { the job and lack of } \\
\text { difficulty due to } \\
\text { the monotony of } \\
\text { the job. }\end{array}$ & $\begin{array}{l}\text { The job content } \\
\text { plateau - same as } \\
\text { Bardwick }\end{array}$ & & $\begin{array}{l}\text { The subjective plateau - } \\
\text { the employee's } \\
\text { feelings that career is } \\
\text { unlikely to develop }\end{array}$ \\
\hline & $\begin{array}{l}\text { The life plateau - is } \\
\text { the state of feeling } \\
\text { stagnant or } \\
\text { trapped in all } \\
\text { areas of life due to } \\
\text { the employees' } \\
\text { failure in their } \\
\text { jobs and lack of } \\
\text { satisfaction. }\end{array}$ & $\begin{array}{l}\text { The inclusive } \\
\text { plateau - the } \\
\text { stagnation in } \\
\text { organizational } \\
\text { centralization, the } \\
\text { lack of authority } \\
\text { and power of the } \\
\text { decision-making } \\
\text { mechanism. }\end{array}$ & & \\
\hline
\end{tabular}

Source: Compiled by the authors. 


\section{N. Yavuz Aksakal - E. Ulucan 13/4 (2021) 3164-3180}

The employee may not have the opportunity to rise and develop in the career due to reasons arising from himself/herself or the organization. The employee's inability to adapt to organizational processes and changes, her inability to develop herself/himself, and her/him inability to comply with the qualifications required by the job can lead to an individual-oriented plateau. Factors such as the organization's inability to foresee environmental changes, lack of structural coordination, inconsistencies in human resources policies, organizational downsizing or regression of institutional growth, organizational climate, can also cause organizational-oriented plateaus (Sadullah et al., 2015: 275; Clark, 2004). In addition, Chao (1990) argues that career plateau can be evaluated as a subjective situation influenced by the perceptions of employees rather than an objective career situation. As can be seen, factors in both individual and structural types and objective or subjective structures can be effective in preventing the progress of the individual in his/her career.

On the other hand, it is possible that career plateau originates from the individual. The fact that the employee is not interested in the higher position and the employee is not considered suitable for the higher position due to some personal weaknesses are also seen for individual reasons (Burke, 1989: 295; Burke \& Mikkelsen, 2006: 692). In addition, situations such as wanting to spare time for the family, not wanting additional responsibilities or new duties can be counted as individual reasons (Clark, 2004). It is stated that understanding whether the individual considering subjective perceptions rather than objective factors is at the plateau stage or not can give more accurate results (Cheng \& Su, 2017).

Career management is one of the issues with cronyism effect in organizations, especially in human resources. Career plateau, which is among the career problems, is considered as a career stage in which the individual perceives that there is no job challenges, as well as the low probability of getting promoted (Yang et al., 2018). Any cronyism that can be made in recruitment processes, career management and promotion processes, wage increases and performance evaluation issues with the effect of cronyism may cause various emotional and behavioral consequences, especially on other employees in the organization. In addition, acting with the effect of cronyism especially in recruitment processes, career management and promotion processes may be harmful to third individuals (in terms of candidates for the position), and may not meet the principle of person-job harmony in a healthy way. The employee whose career development stagnates with the effect of cronyism will enter a stagnant period by experiencing a plateau.

\section{Related Works}

Although cronyism and career flattening are seen in many sectors and business structures, they are more prominently felt in labor-intensive service sectors based on manpower rather than in sectors based on mechanical production. In the literature review, it was revealed that the studies generally focused on service sectors for this reason.

Within the scope of the research, primarily domestic and foreign literature on cronyism was examined and it was seen that the studies mostly focused on the issues of cronyism's job satisfaction, intention to leave, organizational deviation, and possible effects on workload. In almost all of the studies, the negative effects of cronyism on both employees and enterprises have been revealed. Such that Fu found, in a study conducted in 2015, that individuals who were favored in the workplace were promoted much faster than others because of favouritism. Loewe et al. (2007) argued that the employment of unskilled personnel is on the rise due to favouritism.

In the research of Blase and Blase (2003), it was revealed that cronyism affects not only material facts but also decision processes, and it is understood that cronyism is applied in matters such as working conditions of employees and leave rights. On the other hand, Xin-Zhi et al. (2010) concluded that cronyism can also lead to small groupings in enterprises. In connection with this result, many other studies reveal that employees who are less supported due to cronyism in organizations experience situations such as organizational injustice, loss of motivation, decrease in performance, decrease in job satisfaction, loss of trust, decrease in organizational commitment, cynicism and ultimately intention the leave (Abdalla et al., 1998; Yan \& Bei, 2009; Chandler, 2012; Fu, 2015; Argon, 2016; Shaheen et al., 2017; Çetinkaya \& Tanış, 2017; Akçin, 2019).

When the literature on career plateau was examined, it was seen that studies focused on which situations can be evaluated as career plateau and the effects of career plateau. Appelbaum and Finestone (1994) stated in their study that slow economic growth in enterprises increases competition for high-level positions, and noted 


\section{N. Yavuz Aksakal - E. Ulucan 13/4 (2021) 3164-3180}

that some or all employees waiting to be promoted to high-level positions may remain in a plateau position for a certain period of time. In another study, it is stated that the failure of employees' promotion expectations to be positive can create a hierarchical plateau. This results in low satisfaction and low organizational commitment (Yang et al., 2018).

Looking at the studies on the effects of career plateau, the research conducted by Lapalme, Tremblay and Simard in 2009 stands out. In the study, it was revealed that employees who are in a structural plateau experience various psychological difficulties due to the increase in anxiety level and low morale. These difficulties have also been examined in other studies, and as a result of the studies, it was stated that the career plateau led to results such as low job satisfaction, decrease in organizational commitment, intention to leave and absenteeism (Wang et al., 2014; Godard et al., 2015; Cheng \& Su, 2017; Özçelik, 2019). Unlike all other studies, Lee discussed the positive aspects of the concept in a study, conducted in 2003 by revealing that employees perceive the plateau process as a safe and stable rest period due to the feeling of stress and restriction arising from a continuous career mobility.

When the studies on tourism enterprises are examined, it is seen that foreign literature focuses on the effects of cronyism on sectoral development and both regional and national economy. However, cronyism has been discussed in terms of cooperation between investors and public administrators in terms of tourism investments (Prideaux, 1999; Diwan et al., 2014; Adair \& Abdallah, 2015).

In the domestic literature review for the tourism sector, it was emphasized that the researchers focused more on nepotism, another type of favouritism in general. In their study; Arslaner, Erol and Boylu (2014); compared the relationship between nepotism and the perception of organizational justice in terms of accommodation businesses that operate as family businesses and those that do not. According to the results of the study, while there was no negative relationship between nepotism perception and organizational justice in accommodation enterprises operating as a family business, the significant and negative relationship between nepotism and organizational justice was strongly demonstrated in other accommodation enterprises. In the same way, Bolat et al. (2017) have shown that nepotism has a positive effect on the intention to leave work, that is, the high perception of nepotism also increases the intention to leave work. However, in its influence on the intention to leave work, they emphasized that the career plateau created by perceived nepotism also plays a role as an intermediary.

In other studies on cronyism, it was concluded that cronyism in tourism enterprises are frequently perceived in tourism enterprises and have negative effects on employees. According to the common results of the studies, while cronyism significantly decreases the job satisfaction and organizational justice perceptions of the employees, it also increases the perceptions of the intention to leave and career plateau (Erdem et al., 2013; Karataş, 2013; Şapçılar, 2017).

\section{Methodology}

\subsection{The Aim and Importance of Research}

The main aim of this research is to determine whether cronyism behaviors that are frequently encountered in enterprises and are also mixed with nepotism are perceived in tourism enterprises or not. In addition, measuring the effect of perceived chronism behavior on tourism employees is another goal of the study. During the literature review, studies on chronism generally focused on the effect of job satisfaction, turnover intention, and organizational deviation. No study has been found examining the direct effect of chronism on career plateau of employees. Therefore, another purpose of this research is to measure whether the perception of chronism of tourism workers has an effect on the career plateau. From this point of view, it is assumed that the research will also contribute to this lack of literature and create awareness of executive behavior. Istanbul Commerce University Ethics Committee approval was obtained for the interview questions.

\subsection{Sampling and Data Gathering}

Research is designed with an exploratory research pattern and has qualitative characteristics. In the research, firstly, existence of the research problem which can be explained with the perception of cronysim in tourism enterprises, and then, the behavioral and intellectual results caused by this problem were tried to be revealed. The data were collected by the interview technique, a method commonly used in qualitative research, and 


\section{N. Yavuz Aksakal - E. Ulucan 13/4 (2021) 3164-3180}

participants were asked eight questions through a semi-structured question form. The reason for using this method is that; it allows the researcher to dig deeper and collect comprehensive information if it is necessary.

The universe of the research includes all tourim employees work in Istanbul and the sampling contains 23 tourism employees which are determined by snowball sampling method. In determining the sample, the focus was not specifically on a single type of tourism business. In order for the sample to represent the entire sector, individuals working in different types of businesses were preferred. Since the answers received in the interviews started to be repeated frequently after a while, the interviews were terminated after the twentythird participant.

\subsection{Data Analysis and Reliability}

The data collected in the research was analyzed by the content analysis method, which is frequently used in qualitative research analyses. Content analysis is defined as determining which concepts, events and thoughts are most or least emphasized by looking at the content of written texts, images or discourses and reaching a conclusion (Kozak, 2015). The main goal in content analysis is to reach concepts and relationships that can explain the collected data (Yıldırım \& Şimşek, 2016:242). In content analysis, qualitative research data obtained through interviews, observations or documents are analyzed in four stages. First of all, the data is encoded, and then the main themes to which the data will be grouped are determined. These determined codes and themes are organized and at the last stage, the findings are defined and interpreted according to these codes and a research report is written (Kincal, 2015: 192).

At the first stage of the analysis, the audio recordings used during the interviews were transferred to a computer environment and written, and as a result a document of about 47 pages was obtained. Later, in order to check whether spelling mistakes were made, this document was read to two different independent academics and checked.

In the reliability measurements of qualitative research, as reliability and confirmability of results are more prominent than quantitative research, the member control method is applied in order to increase reliability. By the member control method, after all the information recorded by the researcher is written, the interviewees are read and confirmed their accuracy (Erdoğan, 2012). The data obtained in this study were also read and confirmed to the participants and their accuracy was confirmed.

\section{Results}

The information obtained were re-read with the scope of employees' perceptions of cronyism and career plateau, and then the most related and frequently repeated statements were determined with eight questions. The words which are included in these phrases and have common meanings have been coded in order to complete the analysis. Afterwards, all these phrases and codes were analyzed and the thoughts that each interview question tried to reveal were interpreted in a descriptive way.

During the interpretations, the answers given by the participants were also quoted and included in the findings in order to show their point of view. In accordance with the protection of personal data and information privacy, the names and institutions of the participants were not included in the writing of the findings and the citations made, but instead all participants were defined as $P_{1}, P_{2}, P_{3}$, etc. In the direct quotations used, in order not to disturb the integrity of the research and the language flow, daily expression and expression disorders have been changed in a way that does not affect their original meanings. In long answers, only expressions indicating the answers sought by the interview question were shown, and the abbreviations are indicated with ( ... ). The results are shown as following headings.

\subsection{Results of Descriptive Statistics}

At the beginning of the interview, participants were asked demographic questions such as age, educational status, and time of seniority in the sector. All participants interviewed work at different levels in businesses involved in the tourism sector. Data on the demographic distributions of participants are shown in Table 3. 
N. Yavuz Aksakal - E. Ulucan 13/4 (2021) 3164-3180

Table 3. Descriptive Statistics of the Participants

\begin{tabular}{|c|c|c|c|c|c|c|}
\hline Participants & Gender & Age & Education & $\begin{array}{l}\text { Department/ } \\
\text { Position }\end{array}$ & $\begin{array}{c}\text { Working } \\
\text { Time } \\
\text { Period in } \\
\text { Current } \\
\text { Position } \\
\end{array}$ & $\begin{array}{c}\text { Total } \\
\text { Working } \\
\text { Time Period } \\
\text { in the } \\
\text { Company }\end{array}$ \\
\hline $\mathbf{P}_{1}$ & Male & $31-40$ & Graduate & $\begin{array}{c}\text { Events/ Marketing } \\
\text { Manager }\end{array}$ & 4,5 yrs. & 7,5 yrs. \\
\hline $\mathbf{P}_{2}$ & Female & $21-30$ & Postgraduate & $\begin{array}{c}\text { Reservations } \\
\text { Specialist } \\
\end{array}$ & $2,5 \mathrm{yrs}$. & $4,5 \mathrm{yrs}$. \\
\hline $\mathbf{P}_{3}$ & Male & $21-30$ & Graduate & Events Specialist & 4 yrs. & 4 yrs. \\
\hline $\mathbf{P}_{4}$ & Female & $21-30$ & Graduate & $\begin{array}{c}\text { Asst. of } \\
\text { Accounting } \\
\text { Specialist }\end{array}$ & 2 yrs. & 4 yrs. \\
\hline $\mathbf{P}_{5}$ & Male & $21-30$ & Postgraduate & Sales Specialist & 3,5 yrs. & 5 yrs. \\
\hline $\mathbf{P}_{6}$ & Male & $21-30$ & Graduate & $\begin{array}{c}\text { Front Office / } \\
\text { Concierge }\end{array}$ & 3 yrs. & 3,5 yrs. \\
\hline $\mathbf{P}_{7}$ & Male & $31-40$ & Graduate & Revenue Manager & 2 yrs. ${ }^{*}$ & 2 yrs. $8 \mathrm{mts}$. \\
\hline $\mathbf{P}_{8}$ & Male & $31-40$ & Graduate & $\begin{array}{l}\text { Front Office } \\
\text { Manager }\end{array}$ & $1 \mathrm{mts}$. & 3 yrs. 3 mts. \\
\hline $\mathbf{P}_{9}$ & Male & $21-30$ & Ass. Degree & $\begin{array}{c}\text { Group Sales } \\
\text { Representative }\end{array}$ & 1 yrs.* & 1 yrs. \\
\hline $\mathbf{P}_{10}$ & Male & $21-30$ & Postgraduate & $\begin{array}{l}\text { Operations } \\
\text { Executive }\end{array}$ & $\begin{array}{l}2 \text { yrs. } 6 \\
\text { mts. }\end{array}$ & 2 yrs. $8 \mathrm{mts}$. \\
\hline$P_{11}$ & Female & $31-40$ & Graduate & $\begin{array}{l}\text { FIT Operations } \\
\text { Executive }\end{array}$ & $\begin{array}{l}\text { yrs. } 9 \\
\text { mts. }\end{array}$ & 1 yrs. $9 \mathrm{mts}$. \\
\hline $\mathbf{P}_{12}$ & Female & $31-40$ & Graduate & $\begin{array}{c}\text { Agency Contract } \\
\text { Manager }\end{array}$ & 3 yrs. & 3 yrs. \\
\hline $\mathbf{P}_{13}$ & Female & $41-50$ & Graduate & $\begin{array}{c}\text { Marketing } \\
\text { Specialist }\end{array}$ & $\begin{array}{c}10 \text { yrs. } 6 \\
\text { mts. }\end{array}$ & 10 yrs. 6 mts. \\
\hline $\mathbf{P}_{14}$ & Female & $31-40$ & Graduate & Revenue Manager & $\begin{array}{l}1 \text { yrs. } 2 \\
\text { mts. }\end{array}$ & 1 yrs. 2 mts. \\
\hline $\mathbf{P}_{15}$ & Male & $21-30$ & Graduate & $\begin{array}{c}\text { Sales } \\
\text { Representative }\end{array}$ & $\begin{array}{l}2 \text { yrs. } 9 \\
\text { mts. }\end{array}$ & 3 yrs. 6 mts. \\
\hline $\mathbf{P}_{16}$ & Female & $21-30$ & Ass. Degree & Sales Manager & $2,5 \mathrm{yrs}$. & 6 yrs. $2 \mathrm{mts}$. \\
\hline $\mathbf{P}_{17}$ & Male & $21-30$ & Graduate & $\begin{array}{l}\text { Front Office } \\
\text { Supervisor }\end{array}$ & $\begin{array}{c}1 \text { yrs. } 10 \\
\text { mts. }\end{array}$ & 3 yrs. 4 mts. \\
\hline $\mathbf{P}_{18}$ & Female & $21-30$ & Graduate & $\begin{array}{c}\text { Tour Sales } \\
\text { Representative }\end{array}$ & $\begin{array}{l}2 \text { yrs. } 7 \\
\text { mts. }\end{array}$ & 2 yrs. $7 \mathrm{mts}$. \\
\hline $\mathbf{P}_{19}$ & Male & $31-40$ & Graduate & $\begin{array}{l}\text { Accounting } \\
\text { Specialist }\end{array}$ & $\begin{array}{l}3 \text { yrs. } 9 \\
\text { mts. }\end{array}$ & 3 yrs. 9 mts. \\
\hline $\mathbf{P}_{20}$ & Female & $31-40$ & Ass. Degree & $\begin{array}{l}\text { Abroad Travel } \\
\text { Representative }\end{array}$ & 3 yrs.* & $3 \mathrm{mts}$. \\
\hline $\mathbf{P}_{21}$ & Male & $21-30$ & Graduate & Visa Consultant & $\begin{array}{l}1 \text { yrs. } 9 \\
\text { mts. }\end{array}$ & 1 yrs. 9 mts. \\
\hline $\mathbf{P}_{22}$ & Female & $31-40$ & Graduate & $\begin{array}{c}\text { Guest Relation } \\
\text { Manager }\end{array}$ & $\begin{array}{l}1 \text { yrs. } 9 \\
\text { mts. }\end{array}$ & 10 yrs. $8 \mathrm{mts}$. \\
\hline $\mathbf{P}_{23}$ & Male & $31-40$ & Graduate & $\begin{array}{c}\text { Sales } \\
\text { Representative }\end{array}$ & 2. yrs. & 2 yrs. \\
\hline
\end{tabular}

*Participant $\# 7$ is working in the same position, with different companies, since 7 years; $\# 9$ since 3 years and \#20 since 11 years. 
According to the table, it can be said that the gender of the participants distributed nearly equal (13 male and 10 female). According to their age groups, it is seen that the $(52,18 \%)$ of the participants are between $21-30$ while the $(43,48 \%)$ are between $31-40$. Only three people are graduated from associate degree programmes, and the rest have at least graduate degree. When their positions are examined, it is understood that 5 of them are in the level of representative and the rest 18 are in supervisoral or managerial levels. All participants work since at least one year in their companies. When their total time period worked in current positions and companies are compared, it can be said that most of them get promoted in a short time. The most notable point of this table is some employees $\left(\mathrm{P}_{13}\right)$ have been working in the same position in the same company for a long time, and some participants $\left(\mathrm{P}_{7}, \mathrm{P}_{9}\right.$ and $\left.\mathrm{P}_{20}\right)$ have always been working in the same position for a long time within different companies.

The data gathered from the interview questions were read after they were written and during the readings, words or groups of words in the descriptive character included in the text, were noted. In this way, the codes that form the basis of content analysis were created. These codes cover the most frequently repeated and striking statements that are emphasized as important in the statements explaining each interview question. As a result of the analysis, the codes and findings determined for each question are described in two subheadings, respectively, together with the related tables.

\subsection{Results of Cronyism Perception}

The first half of the interview questions were aimed at determining the employees' perception of cronyism, and a total of four questions were asked. The responses of the participants are encoded with expressions with common meanings and shown in Table 4.

Table 4. Findings about the Perception of Cronyism

\begin{tabular}{|c|c|}
\hline Interview Question & Codes \\
\hline $\begin{array}{l}\text { 1. The situation of employess affinity with } \\
\text { the managers they work with }\end{array}$ & $\begin{array}{l}\text { Not directly related (17) } \\
\text { Previously acquainted (6) } \\
\text { There are some who are previously acquainted (20) }\end{array}$ \\
\hline $\begin{array}{l}\text { 2. Whether employees are treated equally, } \\
\text { what kind of discriminations are done. }\end{array}$ & $\begin{array}{l}\text { Treated equally (9) } \\
\text { No comment (3) } \\
\text { Not treated equally (11) } \\
-\quad \text { Priority in recruitment (2) } \\
-\quad \text { Difference on ratio of salary rise (3) } \\
-\quad \text { Difference on distribution of workload (2) } \\
-\quad \text { Departmental discrimination (6) } \\
-\quad \text { Favorism of seniors (4) } \\
-\quad \text { Priority on the rights of flexible work shifts (2) } \\
-\quad \text { Inequalities in programming annual leaves (2) }\end{array}$ \\
\hline $\begin{array}{l}\text { 3. What is understood with the concept of } \\
\text { cronyism. }\end{array}$ & $\begin{array}{l}\text { Any kinds of supports (6) } \\
\text { Positive discrimination (4) } \\
\text { Favouritism (9) } \\
\text { Attitudes like nepotism (6) } \\
\text { Being unethical (1) } \\
\text { Mobbing (1) } \\
\text { No comment (1) }\end{array}$ \\
\hline $\begin{array}{l}\text { 4. The feelings of behavioral differences } \\
\text { arising from cronyism. }\end{array}$ & $\begin{array}{l}\text { Motivation loss (5) } \\
\text { Injustice (10) } \\
\text { Loss in sense of belonging (4) } \\
\text { Loss of organizational commitment (2) } \\
\text { Not felt any kinds of discrimination (3) } \\
\text { Not bothering me (3) } \\
\text { Cynical behaviors (6) } \\
\text { - Diverging from colleagues (1) } \\
\text { - } \quad \text { Scepticism (1) } \\
\text { - } \quad \text { Feeling of inadequacy (1) }\end{array}$ \\
\hline
\end{tabular}




\begin{tabular}{|l|l|}
\hline & $-\quad$ Displaying passive resistance (1) \\
& $-\quad$ Hindering of works (2) \\
\hline
\end{tabular}

When the answers are examined, it is seen that the vast majority of participants are aware of the existence of employees who know each other in advance and are even related, although they do not know one-to-one (friends) in the business in advance. Especially in their answers to the second question, it is understood that this acquaintance leads to behavioral differences in enterprises and these differences are reflected in the employees. Participants mostly complain about the priority in recruitment, the change in salary increase rates according to the individual, and the fact that managers approach some departments more optimistically just because they are on good terms with the people there. Some of the participants' comments on this issue are as follows:

"No. There have been discriminations according to affinity in recruitment, salary increase and project distributions. Such as; hiring the relatives of manager firstly, getting more increased salaries with the help of related managers, and distribution of the important projects only to colleagues who are related with supervisors, etc... $\left(P_{1}\right)^{\prime \prime}$

"Although it seems to be treated the same, it is not. Whoever is closer to the right person, is profitable at the end of the day. This profitability shows itself sometimes in the business department, sometimes about flexible working, sometimes in the salary increase $\left(P_{11}\right) . "$

"Direct distinction is made as loved and unloved personnel. People who do everything they are told and do not object are accepted as loved staff, people who seek their right are not loved and are subjected to all kinds of compulsion... $\left(P_{20}\right)^{\prime \prime}$

When these answers are evaluated, it is understood that the participants are mostly informed about the concept of cronyism. Along with the answers given in the form of nepotism and discrimination of relatives, which are also known definitions of cronyism in the literature, the most noticeable point is that some participants see cronyism as positive discrimination. These participants define cronyism as "positive discrimination, which refers to employees whose work knowledge is trusted and whose previous work discipline is observed". But it is often emphasized in the literature that chronism does not have such a contribution to employees and businesses. At this point, it should also be taken into account why participants think this way.

Finally, in responses to how behavioral differences arising from cronyism make participants feel; it seems that the most featured response is the feeling of injustice and loss of motivation. Therewithal, participants also emphasize that they experience cynical behaviors (scepticism, distance to the team, deliberately disrupting of work, etc.) due to the loss of motivation they experience. It is understood from the answers that this situation also damages the feelings of organizational commitment of the employees. Some direct answers of participants on this topic are summarized as follows.

"It makes me feel far away, in terms of close friendship relationships and the establishment of social networks. $I^{\prime} m$ starting to reduce my self-sacrifice, and giving up to make extra labor $\left(\mathrm{P}_{4}\right)^{\prime \prime}$

"... In fact, treating employees unfairly has a negative turn to the company as well as to staff communication. At some point, you switch to passive resistance. Around me, there are employees who do not work or disrupt even the jobs that will result in a positive result because of their anger at the institution. I couldn't get to that stage because of my ethical understanding, but I can't find those, who did it, guilty anymore... (P13)."

"I'm running out of respect for my company. My desire and motivation to work are disappearing. I never want to add anything to the company $\left(P_{20}\right) "$

When all these answers are examined together, it is understood that the individuals working in tourism industry are aware of the croniysm behaviors in the companies and that these behaviors create many negative feelings on them. So much so that many participants are getting cynical increasingly, and feel distrust to their companies because they have lost their faith in organizational justice. 


\subsection{Results of Career Plateau}

The last four questions, containing the second part of the interview, are aimed at determining whether career plateau occurs in individuals with a perception of cronyism. The answers given by the participants are encoded and shown in Table 5.

Table 5. Findings about the Career Plateau Perception of Participants

\begin{tabular}{|c|c|}
\hline Interview Questions & Codes \\
\hline $\begin{array}{l}\text { 5. What it requires to get promoted in their } \\
\text { companies. }\end{array}$ & $\begin{array}{l}\text { Network (10) } \\
\text { Large client portfolio (3) } \\
\text { Being innovative (6) } \\
\text { Higher customer satisfaction (2) } \\
\text { Business knowlegde (8) } \\
\text { Opening new positions in company (2) } \\
\text { Personal and professional improvement (7) } \\
\text { Job involvement (2) } \\
\text { Being fair (3) } \\
\text { Persistance (2) } \\
\text { Discipline and devotion (5) } \\
\text { Self-respect (1) } \\
\text { Personal advertisement (2) } \\
\text { Familiar manager (3) }\end{array}$ \\
\hline $\begin{array}{l}\text { 6. What criteria are taken into account in } \\
\text { applications such as promotion, salary } \\
\text { increase, etc. }\end{array}$ & $\begin{array}{l}\text { Performance (14) } \\
\text { Seniority (9) } \\
\text { Annual inflation ratio (5) } \\
\text { Equal salary rise ratio is implied (3) } \\
\text { Involvement (2) } \\
\text { The affinity to the managerial board (7) } \\
\text { Higher education and foreign languages (2) } \\
\text { Doubtful behaviors (3) }\end{array}$ \\
\hline $\begin{array}{l}\text { 7. How they see themselves in the future } \\
\text { compared to those who work in the same } \\
\text { position in their companies. }\end{array}$ & $\begin{array}{l}\text { No future in this company (2) } \\
\text { In the same position/stable (6) } \\
\text { Will promote (8) } \\
\text { Priorities to seniors (2) } \\
\text { Equal with everyone (4) } \\
\text { Can be a candidate if the currrent manager leaves (2) }\end{array}$ \\
\hline $\begin{array}{l}\text { 8. How they see themselves in the future } \\
\text { generally. }\end{array}$ & $\begin{array}{l}\text { Manager in a different company (2) } \\
\text { Owner of a company (2) } \\
\text { Manager in a different department (3) } \\
\text { Senior manager in the same department (7) } \\
\text { Manager abroad (2) } \\
\text { More experienced (7) } \\
\text { A different sector (4) } \\
\text { Freelance working (1) } \\
\text { No comment (1) }\end{array}$ \\
\hline
\end{tabular}

According to Table 3, it was observed that a significant proportion of the employees think that the most important thing for promotion in their company is a strong network. At the same time, it is understood that the participants believe that professional knowledge and personal development also play a role in promotion. The most important point here is that some participants think that in order to be promoted, there must be a close relationship with the managers.

Career plateau, which means no career progress in the vertical or horizontal direction in the organization (Tan \& Salomone, 1994), has a contrasting meaning with concepts such as rising in the workplace, promotion, and career developments. Croniysm, on the other hand, refers to the concept of "network", which means 


\section{N. Yavuz Aksakal - E. Ulucan 13/4 (2021) 3164-3180}

membership in a certain group, being rewarded or employed through social relationships and long-term individual relationships, rather than skills and knowledge (Nadler, 2006; Drew et al., 2012). Therefore, the answers of the majority of employees to the fifth question suggest that the presence of cronyism through the network will help in a significant way in order to rise in the workplace, and that if the network is small, there may be a career plateau. In addition, it is possible that employees with a wide network can lead them to a career plateau by surpassing other employees with their career progress. So much so that employees have clearly emphasized this point in their comments as follows.

"I need an executive or a manager who wants me to come some place at work, except for a number of personal developments in order to get promoted. Unfortunately, if you're not good with managers, you can't come to a good place. $\left(P_{18}\right)^{\prime \prime}$

"I've seen that the only way to rise in places where I've ever worked is to lick someones boots or make very close friends. But I really think that attention should be paid to performance, human relationships and personality traits. Unfortunately, this is not the case. $\left(P_{20}\right)^{\prime \prime}$

Participant number 13 answered the same question with similar sentences and took a different approach to the issue, by stating that in order to rise in the company, it is necessary to avoid overly selfless behaviors, because these behaviors do not get the value they deserve. Some of the comments are as follows:

"Having self-esteem, being able to say no and having good relations with the top tier and constantly putting your achievements to the fore. These Personal Ads act as an indoctrination at some point and allow you to create the perception and respect you want... too much work or the fact that the institution benefits from you is not enough alone to rise in your career life... $\left(P_{13}\right)$ "

When the answers of sixth question were examined, it was found that the majority of participants stated that performance and seniority criteria came to the fore. However, three participants emphasized that they felt like they had not been treated transparently enough and therefore suspected that fair practice was being done. Finally, some of the participants explained that the applications for career development were made directly according to the affinity to management. Some of the answers that draw attention to this issue are as follows:

"According to company it's done about performance, uptime, etc. but not according to us. For me, the increases are proportional to how much manager favors you. I think promotions are also related to the affinity to the top squad $\left(P_{11}\right)^{\prime \prime}$

"... Wage increase is done with the logic of how much everyone gets from whom. Whoever is close to management gets the rate they want. The management thinks that the employees don't aware of this, or wants to believe so. $\left(P_{12}\right)^{\prime \prime}$

"The boss determines as he wants, and they are made extremely arbitrariness-oriented. It's about whether the boss is tired of you. It doesn't even matter if you're a useful person. If you're loved, you get a raise and a promotion. $\left(P_{13}\right)^{\prime \prime}$

Finally, according to the answers to the seventh and eighth questions, while most of the participants think that they can be promoted, some of them emphasize that such promotions can only be realized if the people in the current positions resign. For this reason, almost a quarter of participants see their position will remain same in the future. Especially, participant \#13 clearly showed despair for their career future with the comment that "... despite my 12 years of industry experience, I am in a position where I have been for 10 years." As a result of all this, many of them do not even consider working in the same business in the future.

When the answers of questions about career plateau are evaluated in a holistic manner, it is seen that tourism employees think the cronyism behaviors are reflected on their career development implications. This situation causes they give up even their own careers and live career plateauby creating a distrust on them towards company. So much so that as can be understood from the demographic findings and the answers given, some of them have been working in the same position for years. 


\section{Discussion and Conclusion}

Behavioral discrimination, whether cronyism or nepotism, is a common issue in many sectors and businesses. The effects of cronyism on employees have also been frequently investigated in studies and it has been found tere are many negative effects. These effects, seen in many different ways, from the disappearance of organizational commitment to cynicism, ultimately result in leaving the company.

In the literature, studies about behavioral discrimination are mostly focused on nepotism, and oftenly on topics such as the effects of nepotism on organizational justice perception, cynicism, and organizational commitment. In studies about cronyism, issues such as the impact of cronyism on job satisfaction, intention to leave work, organizational deviation, workload have been discussed. These studies have been implied to the tourism sector just as the others. However, no study has been found on whether tourism employees experience career plateau or not, and which correlates this with cronyism. Therefore, the main purpose of this study is to measure whether the perception of cronyism of individuals working in the tourism sector is a reflection of career plateau.

In order to achieve the aim of the research, 23 participants working in different tourism enterprises in Istanbul were interviewed and eight questions were asked. The first half of the questions are intended to measure perceptions of cronyism and the other half are aimed at measuring perceptions of career plateau. When the answers are examined, it is seen that the majority of employees are aware of the existence of employees who know each other, relatives and friends in their companies. This closeness reveals that cronyism, a.k.a friend cronyism, is also often perceived by employees.

The effetcs of cronyism shown on employees suc as perception of injustice and cynical behaviors, especially loss of motivation. From this point of view, the results of this study also match with the results of studies conducted by Yan and Bei (2009), Chandler (2012), Fu (2015) and Argon (2016) in the literature. Because in their studies, it was emphasized that cronyism leads to results such as decreased motivation, loss of performance, decreased organizational commitment and trust in employees. Based on the answers given that cronyism creates a sense of injustice, it is recommended to measure the possible dimensions of the relationship between cronyism and organizational justice in further studies.

It is one of the most remarkable results that employees do not see a future in their own companies when the answers to questions about career flattening are examined. Especially as participants \#11, \#12 and \#13 emphasized, the fact of people who are close to managers show faster rises shows that they believe as they are blocked, so they no longer have expectations about themselves. Such that the twelfth participant commented as, in this regard:

“... if I don't complain so much and accept what are said, do what are told they keep me here for a little while. $\left(K_{12}\right)^{\prime \prime}$

Also, the comments of some participants such as "maybe it will be our turn if the current managers next resign" prove that they have reached a certain level in their career, but after a while it is fixed and they cannot predict the future.

On the other hand, as it can be seen from the demographic findings, the fact that some employees have been working in the same position for more than two years is another proof that participants have experienced a career plateau. In fact, some participants have continued to work in their current positions, including both current companies and previous, for more than 10 years. This is another important conclusion of this research that has been reached regarding the career plateau. Those who have worked in the same position for a long time now experience performance losses, and their organizational commitment is damaged.

As it is emphasized by participants \#13, \#18 and \#20, working in a same position for years creates the perception of they will continue working on the same positions in the future as well, and just because of this, employees start to lose their faith according to the sector not only to their companies. Also these results match with the results of the studies of Applebaum and Finestone (1994), Lapalme et al. (2009), Wang et al. (2014), and Cheng and $\mathrm{Su}$ (2017).

When the findings of this research are cumulatively evaluated, it is clearly seen that the perception of cronyism creates career plateau for employees or one of the reasons of the career plateau of tourism employees is 


\section{N. Yavuz Aksakal - E. Ulucan 13/4 (2021) 3164-3180}

cronyism. No matter which sector it is; as employees face with cronyism, they think that they couldn't get promoted just because of cronyism and cannot plan their career as it is. All of this result with cynical behaviors and being alienated to the companies and the sector itself.

This research has been completed as a pilot study which tried to discover if there is career plateau based on cronyism in tourism companies or not. As a result of the research, it is revealed that cronyism is extremely perceived in tourism sector as well, and behaviors based on cronyism can let-up employees' careers at some level. In order to move this study forward and deepen it for further researches, by enlarging the sample and using the quantitative methods:

- To examine the perception of cronyism in tourism sector with its all dimensions, and

- To determine the direction and power of the relationship between the cronyism and career plateau,

are suggested. In addition, just as in nepotism, the relationship between cronyism and cynicism can be measured and the role of this relationship on career plateau can be investigated.

In terms of industry professionals, it would be appropriate to remind that business managers should treat all employees equally in order to create a successful organizational culture and climate. When starting a new job, although hiring people we know from previous workplaces seems to increase the dynamics of the business, the important point here is to treat all employees objectively as if we meet them for the first time. Otherwise, as this study shows, the motivations of employees will decrease, and employees will deliberately and willingly begin to disrupt their duties. This, in turn, will lead to a situation that affects the overall performance of the business, reducing even the quality of the brand. Thefore for sector professionals;

- Treating all employees equally and fairly,

- By implying accurate human resources management, to plan their employees' careers according to their performances, and

- To make these plans real

are suggested. In order to do this it will be enough to utilize the performance evaluation systems properly and to plan personal and professional development trainings for their employees if necessary.

\section{REFERENCES}

Abdalla, H. F., Maghrabi, A. S. \& Raggad, B. G. (1998). Assessing the effect of nepotism on human resource managers toward nepotism a cross cultural study. International Journal of Manpower. 19(8), 554-570.

Adair, P. \& Abdallah, A. (2015). Overcapacities in the Tunisian tourism industry. 14th International Conference of Middleeast Economic Association (MEEA 2015): Inclusive Growth for Transitional Mena Countries, 23-25 March, Hammamet, Tunisia.

Akçin, K. (2019). Kronizm örgütsel sapma davranışını tetikler mi? Bir yerel yönetim çalışması. İnsan ve Toplu Bilimleri Araştırmaları Dergisi, 8(2), 1330-1345.

Appelbaum, S.H. \& Finestone, D. (1994). Revisiting career plateauing: Same old problems - Avantgarde solutions, Journal of Managerial Psychology. 9(5), 12-21.

Argon, T. (2016). Öğretmen görüşlerine göre ilkokullarda yöneticilerin kayırmacılık davranışları, Kastamonu Ĕ̆itim Dergisi. 24(1), 233-250.

Arslaner, E, Erol, G. \& Boylu, Y. (2014). Konaklama işletmelerinde nepotizm ve örgütsel adalet algısı üzerine bir araştırma. Muğla Sıtkı Koçman Üniversitesi Sosyal Bilimler Enstitüsü Dergisi, 32, $62-77$.

Blase, J. \& Blase, J. (2003), The phenomenology of principal mistreatment: Teachers' perspectives, Journal of Educational Administration, 41(4), 367-422.

Baoguo, X. \& Mian, X. (2005). An empirical research on causes and effects of career plateau. Proceedings of the 7th International Conference on Innovation \& Management, 1729-1732.

Bardwick, J.M. (1986). The Plateauing Trap, New York, USA, . Bantam Books. 


\section{N. Yavuz Aksakal - E. Ulucan 13/4 (2021) 3164-3180}

Boadi, E. G. (2000). Conflict of interest, nepotism and cronyism. In J. Pope (Ed.) Confronting Corruption: The Elements of A National Integrity System, Transoarency International, Berlin, Germany.

Bolat, O. İ, Bolat, T., Seymen, O. \& Katı, Y. (2017). Otellerde nepotizm (akraba kayırmacıllğı) ve işten ayrılma niyeti ilişkisi: Kariyer düzleşmesinin aracılık etkisi. Manas Sosyal Araştırmalar Dergisi, 6(3), 157-180.

Burke, R.J. (1989). Examining the career plateau: Some preliminary findings. Psychological Reports, 65, 295-306.

Burke, R.J. \& Mikkesen, A. (2006). Examining the career plateau among police officers, Policing: An International Journal, 29 (4), 691-703.

Büte, M. (2011). Kayırmacılığın çalışanlar üzerine etkileri ile insan kaynakları uygulamaları ilişkisi: türk kamu bankalarına yönelik bir araştırma, Atatürk Üniversitesi Sosyal Bilimler Enstitüsü Dergisi, 15(1), 383-404.

Chao, G.T. (1990). Exploration of the conceptualization and measurement of career plateau: A comparative analysis. Journal of Management, 16, 181-193.

Cheng, J.W. \& Su, T.W. (2017). Career plateauing and institutional/occupational intention for Taiwanese career officers, Military Psychology, 25 (2), 156-165.

Chandler, J.L. (2012). Black Women's Perceptions of the Relationship among Nepotism, Cronyism Job Satisfaction, and Job-Focused Self-Efficacy, PhD Thesis, The University of San Fransisco, The Faculty of the School of Education.

Clark, J.W. (2004). Marketing management implications of career plateauing. Problems and Perspectives in Management, 2(4), 201-205.

Çetinkaya, A. Ş. \& Sanioğlu Tanış, Z. (2017). Örgütlerde kayırmacılığın iş yükü algısına etkisi: Konya kamu kurumları araştırması. Uluslararası İktisadi ve İdari İncelemeler Dergisi, 16. UİK Özel Sayısı, 607-618.

Diwan, I., Keefer, P. \& Schiffbauer, M. (2014). Pyramid capitalism: Cronyism, regulation and firm productivity in Egypt. Harvard University Center for International Development Working Papers, 291, 1-38.

Drew, A., Kriz, A., Keating, B. \& Rowley, C. (2012). Beyond cronyism: In pursuit of deep trust. 38th Annual Conference of the European Business Academy, 1-21.

Erdem, B., Çeribaş, S. \& Karataş, A. (2013). Otel işletmelerinde çalışan işgörenlerin kronizm (eş dost kayırmacılığı) algıları: İstanbul'da faaliyet gösteren bir, iki ve üç yıldızlı otel işletmelerinde bir araştırma, Çukurova Üniversitesi İktisadi ve İdari Bilimler Fakültesi Dergisi, 17(1), 51-69.

Erdoğan, İ. (2012). Pozitivist Metodoloji ve Ötesi-Araştırma Tasarımları, Niteliksel ve İstatistiksel Yöntemler, İstanbul, Erk Yayıncilik.

Ference T.P., Stoner J.A. \& Warren E.K. (1977). Managing the career plateau. Academy of Management Review, 2(4), 602-612.

Fu, I.P. (2015). Favoritism: ethical dilemmas viewed through multiple paradigms. The Journal of Values-Based Leadership, 8(1), 1-7.

Godard, C., Fouque, T., Gollety, M. \& Flanchec, A.L. (2015). Career plateauing, job satisfaction and commitment of scholars in French universities, Public Organization Review, 15, 335-351.

Hernandez, E. H. \& Page, R. A. (2006). Nepotism in the employment recruitment process: How nepotism builds organizational commitment. Journal of Business Management and Change, 1(1), 3-13.

Hurley, A. E., Fagenson-Eland, E. A. \& Sonnenfeld, J. A. (1997). Does cream always rise to the top?: An investigation of career attainment determinants. Organizational Dynamics. 26(2), 65-71.

James, K. (2006). Antecedents, processes and outcomes of collective (group-level) politics in organizations. In E. Vigoda-Gadot \& A. Drory (Eds.), Handbook of Organizational Politics, Edward Elgar Publishing, UK.

Jones, R. G., Stout, T. Harder, B. Levine, E. Levin, J. \& Sanchez, J. I. (2008). Personnel psychology and nepotism: Should we support anti-nepotism policies? The Industrial-Organizational Psychologist. 45(3), 17-20. 
Karataş, A. (2013). Otel İşletmelerinde Kronizmin İş Tatmini ve İşten Ayrılma Niyeti Üzerinde Etkileri: Muğla İlinde Bir Araştırma. Masters Thesis, Balıkesir Üniversitesi Sosyal Bilimler Enstitüsü.

Khatri, N. \& Tsang, K. (2003). Antecedents and consequences of cronyism in organizations, Journal of Business Ethics, 43(4), 289-303.

Khatri, N., Tsang, E.W.K. \& Begley, T.M. (2003). Cronyism: the downside of social networking, Academy of Management Proceedings, 2003(1), C1-C6.

Khatri, N., Tsang, E.W.K. \& Begley, T.M. (2006). Cronyism: a cross-cultural analysis, Journal of International Business Studies, 37(1), 61-75.

Khatri, N., Wen, C. Y., Fuei, L. W. \& Geok, T. A. (2008). Cronyism: Antecedents and Consequences. Retrieved: http://citeseerx.ist.psu.edu/viewdoc/download?doi=10.1.1.133.6966\&rep=rep1\&type=pdf.

Kiechel, W. (1984). How to relate to nepotism", Fortune, February, 143-144.

Kıncal, R. (2015). Bilimsel Araştırma Yöntemleri, Ankara, Nobel Akademik Yayıncılık.

Kozak, M. (2015). Bilimsel Araştırma-Tasarım, Yazım ve Yayım Teknikleri, Ankara, Detay Yayıncılık.

Lapalme, M.E., Tremblay, M. \& Simard, G. (2009). The relationship between career plateauing, employee commitment and psychological distress: the role of organizational and supervisor support, The International Journal of Human Resource Management, 20(5), 1132-1145.

Lee, P.C.B. (2003). Going beyond career plateau: Using professional plateau to account for work outcomes. Journal of Management Development, 22, 538-551.

Loewe M., Blume J., Schönleber V., Seibert S., Speer J., \& Voss C., (2007). The impact of favouritism on the business climate: a study on wasta in Jordan. SSRN Electronic Journal, 1-33.

Nachbagauer, A.G.M. \& Riedl, G. (2002). Effects of concepts of career plateaus on performance, work satisfaction and commitment, International Journal of Manpower, 23(8), 716-33.

Nadler J. \& Schulman, M. (2006). Favoritism, Cronyism and Nepotism; Markkula Center for Applied Ethics, Retrieved: https://www.scu.edu/government-ethics/resources/what-isgovernment-ethics/favoritismcronyism-and-nepotism/

Özçelik, M. (2019). Kariyer Platosunun Nedenleri ve Sonuçları: Bankacıllk Sektöründe Bir Araştırma. Masters Thesis, Gazi Üniversitesi Sosyal Bilimler Enstitüsü.

Pearce, J. L. (2015). Cronyism and nepotism are bad for everyone: The research evidence, Industrial and Organizational Psychology, 8 (1), 41-44.

Pelletier, L. \& Bligh, M. C. (2008). The aftermath of organizational corruption: Employee attributions and emotional reactions. Journal of Business Ethics, 80(4), 823-844.

Prideaux, B. (1999). Tourism perspectives of the Asian financial crisi: Lessons for future. Current Issues in Tourism, 2(4), 279-293.

Rotondo, D.M. \& Perrewe, P.L. (2000). Coping with a career plateau: An empirical examination of what works and what doesn't. Journal of Applied Social Psychology, 30, 2622-2646.

Sadullah, Ö., Uyargil, C., Acar, A.C., Özçelik, A.O., Dündar, G., Ataay, İ.D., Adal, Z. \& Tüzüner, L. (2015). İnsan Kaynakları Yönetimi, İstanbul, Beta Yayınları.

Shaheen, S., Bashir, S. \& Khan, A.K. (2017). Examining organizational cronyism as an antecedent of workplace deviance in public sector organizations, Public Personnel Management, 46(3), 308-323.

Soleimanof, S. (2016). Cronyism and Entrepreneurship: An International Analysis of the Influence of Cronyism on Country Level Productive and Unproductive Entrepreneurship, PhD Thesis, Oklahoma State University Faculty of Business Administration.

Şapçllar, M. C. (2017). Turizm Sektöründe Kayırmacılı̆̆ın Etkileri: Otel İşletmeleri Üzerinde Bir İnceleme, PhD Thesis, Necmettin Erbakan Üniversitesi Sosyal Bilimler Enstitüsü. 
N. Yavuz Aksakal - E. Ulucan 13/4 (2021) 3164-3180

Tan C.S. \& Salomone P.R. (1994). Understanding career plateauning: Implications for counseling. Career Development Quarterly, 42(4), 505-534.

Turhan, M. (2014). Organizational cronyism: Ascale development and validation from the perspective of teachers, Journal of Business Ethics, 123, 295-308.

Wang, Y.H., Hu, C., Hurst, C.S. \& Yang, C. C. (2014). Antecedents and outcomes of career plateaus: The roles of mentoring others and proactive personality, Journal of Vocational Behavior, 85(3), 319-328.

Xie, B; Lu, X.; Zhou, W. \& Xin, X. (2014). The effect of career plateau on Chinese employees' affective commitment: An indigenous career plateau scale and two-mediator model. Frontiers of Business Research in China, 8, 346-366.

Xin-Zhi, Z., Hua, X., \& Fei, C. (2010). The normative study of cronyism on Chinese family business. 2010 International Conference on E-Business and E- Government, 1049-1052.

Yan, Y. \& Bei, H. (2009). The antecedents of organizational cronyism. Management and Service Science, 1-4.

Yang, W.N., Johnson, S. \& Niven, K. (2018). That's not what I signed up for! A longitudinal investigation of the impact of unmet expectation and age in the relation between career plateau and job attitudes, Journal of Vocational Behavior, 107, 71-85.

Yıldırım, A. \& Şimşek, H. (2016). Sosyal Bilimlerde Nitel Araştırma Yöntemi, Ankara, Seçkin Yayınevi. 